\title{
Industrial Wastewater Management in Yogyakarta, Indonesia: Direction to Control Industrial Pollution
}

\author{
Astrid Meilasari-Sugiana
}

${ }^{I}$ Universitas Bakrie, GOR Soemantri Brodjonegoro, Kav C-22, Kuningan, Jakarta Selatan 12920, Indonesia.

\begin{abstract}
Increasing competition over decreasing water supply and rapid growth of small and medium enterprises lacking pollution control measures suggest the need for improved institutional framework to manage effluent discharge. The research analyzes the adequacy of institutional arrangements and instruments for managing industrial effluent discharge in Yogyakarta, Indonesia through case study and indepth interviews with purposive sampling. Results suggest overemphasis on prescriptive measures, lack of adequate coordination mechanisms, and lack of effective policy instruments for pollution control among small enterprises. It is necessary to establish an umbrella agency with cross-cutting authority for consistency, to differentiate regulatory and economic instruments for the various industries, to reduce the number of environmental permits, and to introduce incentives for developing industrial estates. Industries contemplate on their actions as the general public is notified of their environmental standing through media coverage within the Clean River Program.
\end{abstract}

Keywords: Industrial wastewater management, institutional arrangements, regulatory measures, economic instruments, deliberative participation.

São Paulo. Vol. 24, 2021

Original Article

DOI: http://dx.doi.org/10.1590/1809-4422asoc20190260r1vu2021L4AO 


\section{Introduction}

Yogyakarta, a medium size city with a population of 3.842 .932 in 2019, has a population density of 1538 persons per square kilometer (BAPPENAS, 2019, p. 13). Sporadic growth of industries such as leather, silver, dying, laundry and food processing contribute to environmental distress should agencies fail to respond accordingly. Micro, small and medium enterprises dominate Yogyakarta's landscape. Many of them operate as home industries within eco-sensitive areas such as riverbanks, lowlands and flood-prone neighborhoods. Their sporadic nature, their incapacity to incorporate environmental care, and their ability to elude pollution control exacerbate water pollution issues within the city. In 2019 the municipal government of Yogyakarta recorded 500 big and medium industries and over 238,600 small and micro enterprises (DEPERINDAG, 2019, p. 17-18). Due to their informal nature, many home industries are not registered in the Chamber of Commerce and/or the Municipal Department of Trade and Industries.

The Hinder Ordonantie Nuisance Permit, the Building Permit and the ANDAL Environmental Management System Audit are mandated by the government to ensure enterprises adhere to the city's spatial plans and incorporate pollution control. Government effort also include initiating zones for uniform types of industries and providing them with communal end of pipe technology. Medium size industries discharge partially treated effluents onto land and rivers, whereas most small and micro enterprises lack communal treatment facilities. Small and medium industries do not voluntarily adopt pollution control; they respond to regulatory mandates. Pollution control is considered the least priority on pretext of financial, technical and spatial constraints.

Weak enforcement causes lack of industrial compliance. The number of taxes and permits imposed by the government is much too cumbersome and its system too complex. It is estimated that only $25 \%$ of Yogyakarta's small and micro industries are connected to the municipal sewerage, and only about $5 \%$ of those industries have access to communal wastewater treatment (DEPERINDAG, 2019 , p. 17). However, in recent years land use planning has run short of proper implementation and enforcement, resulting in haphazard land development. Building permits fall short of their intended function to ensure environmental health and integrated land use. Moreover, the Hinder Ordonantie Nuisance permit functions as rubber stamps, avowing community approval and falling short of its intended function as a comprehensive development tool. In addition, the spurious development of home industries is marked by lack of planning, documentation and integrated permitting system. The above propels the government to promote a more adequate investment act, subsidize pollution control and internalize environmental costs into production costs.

\section{Background: 'Integrated' industrial wastewater management initiatives in Yogyakarta, Indonesia}

There is no Industrial Wastewater Management Act in effect which regulates the cooperation of national, provincial and local governments in managing industrial wastewater discharge. Policies have evolved from existing legislative framework, responding to needs for solving conflicts involving effluent discharge. Several initiatives were made by the national government to develop integrated industrial wastewater management. Four categories of policies, programs and 
taxation system contribute to integrated industrial wastewater management, namely (i) industrial wastewater management-oriented policies, laws and regulations (Environmental Management and Monitoring Plans for Small and Micro Enterprises or Rencana Kelola Lingkungan - RKL/RPL, Environmental Impact Assessment (EIA), Investment Screening for Clean Technology, and Life Cycle Assessment for Large and Medium Industries or Analisis Dampak Lingkungan - AMDAL/ ANDAL), (ii) broader inter-sectoral effluent and surface water management programs (Clean River Program or Program Kali Bersih - PROKASIH), (iii) area specific effluent management programs (collective treatment plants, cleaner production measures and recycling/re-use), and (iv) groundwater withdrawal and industrial effluent charges.

Large and medium enterprises are required to submit their Environmental Impact Assessment (EIA) prior to acquiring investment and operation permits. In addition, they are required to have the Hinder Ordonantie Nuisance Permit and submit the Environmental Management Plans or Rencana Kelola Lingkungan. This is a prerequisite to acquire the Land and Building Permit (Ijin Bumi Bangunan) and the Operation Permit (Ijin Operasional). The Nuisance Permit and the Environmental Management Plans require renewal every five years. The Nuisance Permit is issued by the Mayor of Yogyakarta for enterprises of potential nuisance to surrounding environments. Nonetheless, large and medium enterprises were present prior to the enactment of nuisance permits, while small industries grew from the informal sector within environmentally sensitive areas.

The Clean River Program includes initiatives to map pollutants along the rivers, covenants between government departments and enterprises, and monitoring and enforcement for increased compliance. Industrial effluent discharge and river water quality are monitored every four months by the Environmental Impact Management Agency. Industries are required to submit a report covering the quantity and quality of their effluent discharge. Reports concerning the industries' performance are distributed every six months, while mentoring and consultations are done once every two months. Awards are given for effective pollution mitigation efforts. If not, industries are mandated to compensate for the environmental degradation caused by their production processes. Disclosure of findings through the media, as well as discussions with the general public are conducted periodically.

Table 1. Institutions Involved in Industrial Wastewater Management Program

\begin{tabular}{|c|l|l|l|}
\hline No & Programs & Lead Agency & Supporting Agency \\
\hline 1 & $\begin{array}{l}\text { Mentoring and Con- } \\
\text { sultation on Manage- } \\
\text { ment and Production } \\
\text { (Capacity Building) }\end{array}$ & $\begin{array}{l}\text { Provincial Chamber of Com- } \\
\text { merce and Industry }\end{array}$ & $\ldots$ \\
\hline 2 & $\begin{array}{l}\text { Monitoring the Quantity } \\
\text { and Quality of River Wa- } \\
\text { ter Across Jurisdictions }\end{array}$ & Department of Public Health & $\begin{array}{l}\text { Municipal and Provincial } \\
\text { Environmental Impact } \\
\text { Management Agency }\end{array}$ \\
\hline
\end{tabular}




\begin{tabular}{|c|l|l|l|}
\hline 3 & $\begin{array}{l}\text { Mentoring and Consul- } \\
\text { tation on End of Pipe } \\
\text { Technology and Waste } \\
\text { Emission Prevention }\end{array}$ & $\begin{array}{l}\text { Provincial and Municipal En- } \\
\text { vironmental Impact Manage- } \\
\text { ment Agency }\end{array}$ & $\begin{array}{l}\text { Chamber of Commerce } \\
\text { and Industry } \\
\text { Municipal Government }\end{array}$ \\
\hline 4 & $\begin{array}{l}\text { Disclosure and Discussion } \\
\text { with the Public and Sur- } \\
\text { rounding Communities }\end{array}$ & $\begin{array}{l}\text { Provincial Environmental } \\
\text { Impact Management Agency }\end{array}$ & $\begin{array}{l}\text { Chamber of Commerce } \\
\text { and Industry }\end{array}$ \\
\hline 6 & $\begin{array}{l}\text { Subsidy for Wastewater } \\
\text { Facilitien }\end{array}$ & $\begin{array}{l}\text { Provincial and Municipal En- } \\
\text { vironmental Impact Manage- } \\
\text { ment Agency }\end{array}$ & $\begin{array}{l}\text { Municipal Govern- } \\
\text { ment }\end{array}$ \\
\hline $\begin{array}{l}\text { Production House and } \\
\text { Wastewater Treatment }\end{array}$ & Provincial Government & $\begin{array}{l}\text { Chamber of Commerce } \\
\text { and Industry } \\
\text { Provincial Environmen- } \\
\text { tal Impact Management } \\
\text { Agency }\end{array}$ \\
\hline 7 & $\begin{array}{l}\text { The PROKASIH Clean } \\
\text { River Program }\end{array}$ & $\begin{array}{l}\text { Provincial Environmental } \\
\text { Impact Management Agency }\end{array}$ & $\begin{array}{l}\text { Chamber of Commerce } \\
\text { and Industry } \\
\text { Municipal Environmen- } \\
\text { tal Impact Management } \\
\text { Agency }\end{array}$ \\
\hline 9 & $\begin{array}{l}\text { Wastewater Dischar- } \\
\text { ge Permits and Taxes }\end{array}$ & The Municipal Government \\
tion Process & $\begin{array}{l}\text { Chamber of Commerce } \\
\text { and Industry }\end{array}$ \\
\hline
\end{tabular}

(Source: Interview Transcripts with Respondents, 2018, p. 3)

Institutional arrangements are networked based on existing authorities of relevant agencies and administrative jurisdictions. The participatory nature of industries is key since integration of various policy objectives is pursued through interagency and interjurisdictional coordination. Vertical coordination between national agencies and the sub-national government is conducted through communication, consultation and bargaining. The provincial and municipal government levels are responsible for implementing nationally, provincially and locally funded programs and projects.

The New Public Management strategy advised institutionalizing competitive interactions to motivate individuals and the collective to initiate, implement and disseminate new forms of policies and services. Nonetheless, the conventional perception that public sector innovation is best facilitated through collaboration among interdependent stakeholders still prevail in Indonesia. Both strategies offer insights on how to strengthen innovations within the public sector by recognizing the 
drivers and barriers of competition and collaboration (Sorensen, 2017, p. 215). The government recognizes the importance of competition among industries and government agencies in enabling initiatives and innovations. Nonetheless, the municipal government needs "to pinpoint the cause of the problems, the ambiguities over how the policies are defined, the disagreements concerning how to address the problems, and the difficulties in evaluating governance outcomes" (Sorensen, 2017, p. 219). It is necessary for meta coordinating agencies such as the Environmental Impact Management Agency to know when to encourage stakeholders to compete, under what stipulations, and when to motivate them to collaborate. Braczyk, et.al in Sorensen (2017, p. 219) noted:

In the early stages of the theory development, economic innovation theory viewed competition as the main driver of innovation. Market based competition motivates individual entrepreneurs, as well as firms, to develop new products and production processes. However, over time, collaborations within firms, between firms, between firms and their consumers, and between firms and public authorities have been brought into focus as an important driver of private sector innovation.

The municipal government has recently looked into the roles which quasi-markets, partnerships and networks play in enhancing governance and motivating industries to innovate. Newly established organizations consisting of firms, entrepreneurial associations, the Investment Coordinating Board and consumer groups have become newly derived 'quasi-markets' which 'mandates' clean technology and life cycle assessment during investment screening. Inter-sectoral surface water management programs such as the Clean River Program or Program Kali Bersih PROKASIH requires collaborations between firms, their consumers and the media to provide feedback loops over goal innovation and implementation innovation initiatives. Partnerships between firms are required to enable area specific effluent management programs such as collective treatment plants, cleaner production measures and resource recycling initiatives for industrial estates. In Yogyakarta, officials from the Environmental Impact Management Agency noted the need to go beyond the bureaucratic, compartmentalized, and supply driven forms of regulation mechanism and into how the autonomously interdependent actors formulate and pursue negotiated goals. This is done through self-governance in autonomous spaces where various stakeholders craft policy design and structure incentives geared to reward collaborative actions and shared goals. Officials from the Environmental Impact Management Agency also noted that the metagovernor and coordinator (the Environmental Impact Management Agency and the Sub-National Planning Board), exercise hands-on approach of meta-governing by promoting negotiations among decentralized self-governing entities. This leads to a feedback loop and incorporates bottom-up self-evaluation rather than top-down performance assessments. The notable success of the Clean River Program is due to the flexible, adaptive and bottom-up form of self-evaluation involving small and medium enterprises, local communities, local media, the Provincial Investment Coordinating Board and business associations at the sub-national level. The notable success of the program is also due to the feedback loop provided by small and medium enterprises, consumer groups, local communities, local media, business associations and the Investment Coordinating Board at the sub-national level. This promotes transparency, accountability and good governance on a voluntary and self-adapting measure. 


\section{Research methods}

Quantitative and qualitative inquiries are adopted to enrich knowledge of the field settings. The research assumes the absence of a single perspective and the presence of multiple and incomplete subjectively derived realities. The research assumes complex interdependence between the researcher and subjects and phenomena being studied. Research informants were selected through purposive sampling and issues which arose were used to determine the research subjects invited for interviews. Data collection was conducted through participant observations, in-depth interviews and the compilation of secondary data in relation to government policies, programs and projects in Yogyakarta. A pilot study in Yogyakarta was conducted from August 2017 until October 2017 to acquire connections within the field site and obtain rudimentary data of industrial pollution control programs within the site. Data collection was conducted in six months from March 2018 until August 2018. A total of 117 respondents from various government departments (Table I), industries and community groups were interviewed. Primary data was obtained through qualitative interviews and surveys. The qualitative interviews incorporated story-telling, participant observation, personal narration and observations of group discussion forums. Interview sessions progressed from general to the specific and probes into specific issues within which respondents play a role. Respondents were inquired of their knowledge, involvements and influence in policies, programs and instruments related to industrial wastewater management. Respondents were also inquired concerning their expectations with regard to future policies and programs. The surveys incorporated both open and close-ended questions using the Likert Scale. Descriptive statistics was used to analyze the data, with responses being categorized from most to least frequent in terms of percentages. The interview data was analyzed through coding, categorization, comparison, conceptualization and/or thematization, and a comprehensive analysis of the themes which emerged. Secondary data was used to gain a better understanding of the research informants' perspectives. The New Public Management stream of thought is accentuated to understand its limitations and provide insights on the complex need to coalesce concepts such as competition and collaboration and voluntarism and regulation in industrial wastewater governance.

\section{Adequacy of institutional 'framework' for industrial wastewater management}

This analysis focuses on the institutional framework and movements taking place on a macro scale. Institutional elements integrating government entities which direct industrial effluent management are assessed. According to government officials there are several conditions which can enhance or constrain the coordination effort, namely (i) clarity and consistency of objectives and legal directions, (ii) interagency coordination, (iii) adequacy of statutes to structure implementation, (iv) commitment of implementing officials to the objectives of environmental regulations and programs, (v) participation of target groups in program implementation, and (vi) presence of skillful actors in facilitating implementation. Respondents identified lack of clarity in the target group and function of Ministerial Decree No 10/1994 concerning Letter of Intent for Implementing Environmental Management. If small industries are required to submit Environmental Management and Monitoring Plans (RKL/RPL), then what is the purpose of having to acquire the Letter of Intent for Environmental Management and Monitoring (SPPL)? The Letter 
of Intent (SPPL) was conceptualized as mini-Environmental Management Plans (mini RKL/RPL) for micro and small enterprises incapable of adopting large-scale Environmental Management and Monitoring Plans (RKL/RPL). Initially, the Environmental Management and Monitoring Plan (RKL/RPL) was drafted for large and medium industries. Nonetheless, the Letter of Intent (SPPL) is based on the Environmental Management and Monitoring Plan (RKL/RPL) and lacks clarity in its objectives. Moreover, in order to be legally enforceable, the Environmental Management and Monitoring Plan (RKL/RPL) must be reflected in permits and licenses. Nonetheless often legal establishments and enforcing institutions do not specify the need for Environmental Management and Monitoring Plans (RKL/RPL). Figure 1 depicts the Environmental Impact Assessment (EIA) process for new investments.

\section{Figure 1: Environmental Impact Assessment (EIA) Process for New Investments}

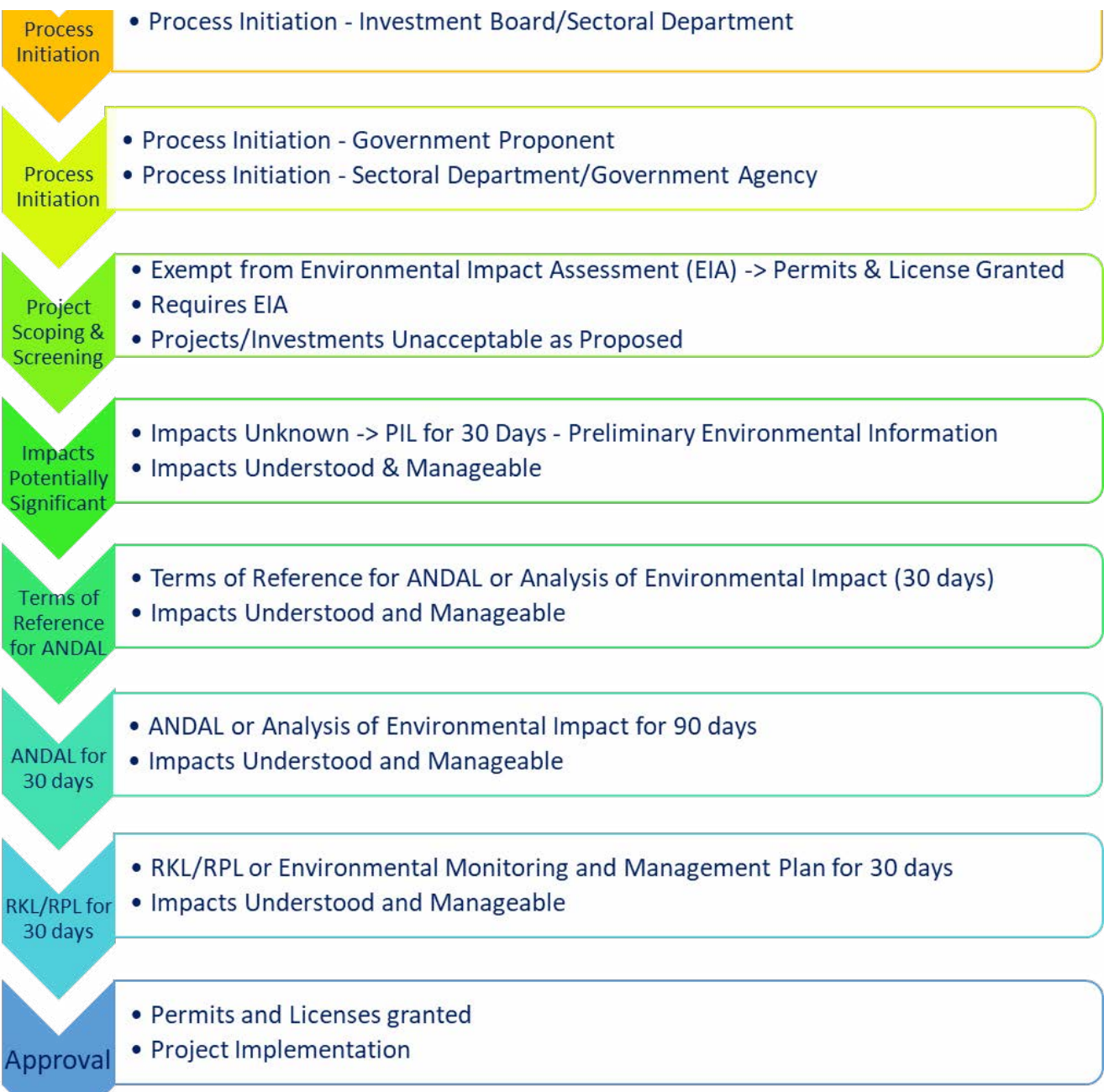

(Source: Bappedalda, 2019, p. 26) 
NGO officials noted a lack of clarity in the administrative procedures to acquire permits related to corporate environmental care. Numerous agencies are responsible for issuing the various required permits and licenses, whereas clear information over the procedures and departments involved is very much lacking. Moreover, permits and licenses are issued by individual sectoral departments, and the sub-national Environmental Impact Management Agencies have no power to overrule their decisions. The EIA agencies have the authority to endow discharge permits solely to enterprises within the Clean River Program. The number of permits and licenses must be reduced, their functions rationalized, and procedures simplified if effective industrial wastewater management is to be integrated through the permit and licensing system.

Table 2. Lack of Clarity in Present Regulatory Framework and Programs

\begin{tabular}{|c|l|}
\hline No & Lack of Clarity in Present Regulatory Framework and Programs \\
\hline 1 & $\begin{array}{l}\text { The function of the Nuisance (HO) Permit: A legal instrument directed } \\
\text { for integrated environmental management or simply an instrument to } \\
\text { ensure approval from surrounding community and to establish agree- } \\
\text { ment to minimize potential nuisances? }\end{array}$ \\
\hline 2 & $\begin{array}{l}\text { The function of Ministerial Decision No10/1994 concerning the Letter } \\
\text { of Intent (SPPL) for implementing Environmental Management and } \\
\text { Monitoring Plans is inconceivable and useless since enterprises will } \\
\text { have to submit an Environmental Management and Monitoring Plan } \\
\text { anyways. }\end{array}$ \\
\hline 3 & $\begin{array}{l}\text { Lack of clarity in the intent of Governor's Decision No 214/1991 con- } \\
\text { cerning Water Quality Standards: to set ambient water quality standards } \\
\text { for different water bodies or to set effluent discharge standards at certain } \\
\text { locations? }\end{array}$ \\
\hline 4 & $\begin{array}{l}\text { Provincial Regulation No 3/1997 concerning the Environmental Mana- } \\
\text { gement and Monitoring Plans (RKL/RPL) for Wastewater Discharge. }\end{array}$ \\
\hline 5 & $\begin{array}{l}\text { Article } 5 \text { of Presidential Decree No 53/1989 dictates that no permit will } \\
\text { be issued until after approval of the Environmental Management and } \\
\text { Monitoring Plans (RKL/RPL). However, Article 5 is not specific about } \\
\text { which permits it applies to. }\end{array}$ \\
\hline 6 & $\begin{array}{l}\text { The mentoring and consultation program on industrial pollution con- } \\
\text { trol and end of pipe treatment for micro, small and medium industries } \\
\text { contain straightforward statement of the target, but lack clear guidance } \\
\text { to follow. }\end{array}$ \\
\hline
\end{tabular}




\begin{tabular}{|l|l|}
\hline 7 & $\begin{array}{l}\text { Public health mentoring and consultation program for micro, small and } \\
\text { medium enterprises aiming to control industrial pollution and promote } \\
\text { end of pipe treatment simply prescribe in vague terms some desired futu- } \\
\text { re state of task and lack clear guidance for implementors to follow when } \\
\text { concerned with pollution control and end of pipe treatment. }\end{array}$ \\
\hline
\end{tabular}

(Source: Interview Transcript with Respondents, 2018, p. 4)

Officials from the Environmental Impact Management Agency noted that the wastewater discharge tax is simply an administrative charge to acquire and renew permits for discharging wastewater. Regulations stipulated that the fee be based on volume of wastewater generated, acting as an economic instrument to internalize measures for reducing pollutants. However, legal directives also mandate the fee be paid only every four years to acquire and renew wastewater discharge permits. The fee is too minimal to induce behavioral changes in discharge patterns. Government respondents also noted a lack of clarity in the groundwater withdrawal tax for industries. In addition to the required charge based on the volume of groundwater extracted, an administration fee is also mandatory for the acquisition of groundwater extraction permit. Table 3 shows the inconsistencies which were identified by statistics appointments with the respondents.

Table 3. Inconsistencies and Conflicts among Policy and Program Objectives

\begin{tabular}{|c|l|}
\hline No & Inconsistencies and Conflicts among Objectives \\
\hline 1 & $\begin{array}{l}\text { Policy to increase the welfare of low-income groups by promoting home } \\
\text { industries could be conflicting without adequate mentoring for imple- } \\
\text { mentation of end of pipe technology and sustainable land use planning. }\end{array}$ \\
\hline 2 & $\begin{array}{l}\text { Legal directives which give the sectoral ministries and departments } \\
\text { the supreme power to execute and enforce environmental regulations } \\
\text { could be in conflict with Presidential Decree No 77/1994 which gives } \\
\text { the Environmental Impact Management Agency power to coordinate } \\
\text { the formulation, monitoring and enforcement of environmental laws for } \\
\text { increased integration and effectiveness. }\end{array}$ \\
\hline 3 & $\begin{array}{l}\text { In the absence of adequate land use and zoning policies, programs to } \\
\text { promote small and micro enterprises could be in conflict with the Pro- } \\
\text { vincial Planning and Development Agency to promote zoning for micro, } \\
\text { small and medium industries. }\end{array}$ \\
\hline 4 & $\begin{array}{l}\text { Mentoring by the Chamber of Commerce to promote increased pro- } \\
\text { duction among micro and small enterprises while maintaining lenient } \\
\text { corporate environmental management is in conflict with Ministerial } \\
\text { Decision No 10/1994 on RKL and RPL and effluent and water quality } \\
\text { standards. }\end{array}$ \\
\hline
\end{tabular}




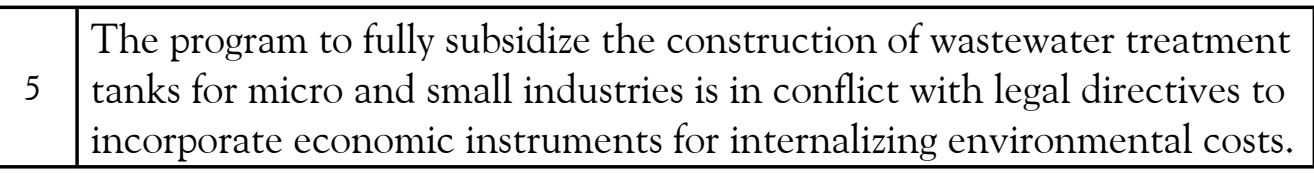

(Source: Interview Transcript with Respondents, 2018, p. 5)

To resolve inconsistencies, an intersecwtoral committee led by representatives from the Environmental Impact Mitigation Agency was established to promote negotiation with representatives from appointed sectoral agencies. Moreover, the Governor's status as a coordinator in implementing all sub-national programs was strengthened by Government regulation No 6/2015.

According to government officials, three categories of coordination mechanisms are incorporated. First, there are procedures mandatory for general coordination of sectoral policies imposed by the central government (e.g. long and short-term development plans, procedures for program and budget proposal, and procedures for Environmental Impact Assessment). Second, there are mechanisms to improve sub-national policy coordination such as the Planning and Development Board's coordinating committee for reviewing budget proposals, and the Environmental Impact Mitigation Agency's intersectoral coordinating committee headed by a representative from the agency. Third, there are informal coordination instruments such as meetings between executives for resolving conflict and solidifying commitments across sectors and jurisdictions. Table 4 below depicts factors which enhanced and constrained the adequacy of procedures for coordination identified by statistics appointments with respondents.

Table 4. Factors Enhancing and Constraining Coordination Procedures and Mechanisms

\begin{tabular}{|c|l|}
\hline No & Factors Constraining Coordination Procedures and Mechanisms \\
\hline 1 & $\begin{array}{l}\text { The combination of vertical and segmented-sectoral oriented approach in } \\
\text { the bureaucratic public administration systems hinder coordination efforts } \\
\text { at the provincial and municipal level and increase conflicts in the permit- } \\
\text { ting system. }\end{array}$ \\
\hline 2 & $\begin{array}{l}\text { Because major initiatives for planning the development budget were made } \\
\text { by the national-sectoral agencies, planning at the provincial and muni- } \\
\text { nationally determined goals. }\end{array}$ \\
\hline 3 & $\begin{array}{l}\text { Limited time allotted for the process of consultation and negotiation. } \\
\text { Heavy reliance on oral communication which caused problems of ineffec- } \\
\text { tive exchanges of information, consultation, collaboration and negotia- } \\
\text { tion among agencies. }\end{array}$ \\
\hline 5 & $\begin{array}{l}\text { Inadequate budget and incapacity of municipal government agencies to } \\
\text { provide information. }\end{array}$ \\
\hline
\end{tabular}




\begin{tabular}{|c|l|}
\hline 6 & $\begin{array}{l}\text { Difficulties in seeking common ground for clarifying responsibilities and } \\
\text { resolving interagency conflicts, a particular party often use legal instru- } \\
\text { ments for supporting its interests which are inconsistent with the legal } \\
\text { and institutional framework underlying the other parties. }\end{array}$ \\
\hline 7 & $\begin{array}{l}\text { Coordination meetings for consensus making are often attended by repre- } \\
\text { sentatives who do not possess authority for decision making on behalf of } \\
\text { their agencies. }\end{array}$ \\
\hline 8 & $\begin{array}{l}\text { Semi-autonomous agencies such as the Environmental Impact Manage- } \\
\text { ment Agency and the Provincial Investment Coordinating Board have } \\
\text { inadequate power to influence sectoral agencies to participate in coor- } \\
\text { dination since they have no control over sectoral budget and resource } \\
\text { allocation. }\end{array}$ \\
\hline 9 & Lack of adequate information and evidence over environmental issues. \\
\hline & Factors Enhancing Coordination Procedures and Mechanisms \\
\hline 10 & $\begin{array}{l}\text { Legitimization for coordination among sectoral project proposals under } \\
\text { the National and Provincial Development Budget imposed by the central } \\
\text { and provincial government. }\end{array}$ \\
\hline 11 & $\begin{array}{l}\text { Gradual improvement of procedures made by the central and provincial } \\
\text { government to accommodate provincial and local needs. }\end{array}$ \\
\hline 12 & $\begin{array}{l}\text { Opportunities given to related agencies within and among levels to meet } \\
\text { together to exchange information, solicit others' views, resolve conflicts } \\
\text { and have discussions to search for common ground. }\end{array}$ \\
\hline 13 & $\begin{array}{l}\text { The need to clarify overlapping responsibilities and seek common ground } \\
\text { for resolving conflicts of objectives and interests. }\end{array}$ \\
\hline 14 & $\begin{array}{l}\text { Presence of skillful actors who can bridge the gaps among agencies such } \\
\text { as the mayors, district heads, governors and staffs from the Provincial } \\
\text { Planning and Development Board (Bappeda). }\end{array}$ \\
\hline
\end{tabular}

(Source: Interview Transcript with Respondents, 2018, p. 5)

Government officials and NGOs noted two variables as key in structuring the implementation process, namely the adequacy of financial support for policy implementation and adequate incentives and sanctions. Government officials noted that financial support for the Clean River Program is substantial, nonetheless without aid from the national development budget, the provincial budget would not have the means to finance a continuous multiyear Clean River Program. The success of the program is due to its high profile and constant appearance in the media, and its clear mandates and legal groundwork for action against polluters, though no legal action to date has been taken on the grounds of the need to promote voluntary cooperation as opposed to forced collaboration. Reasons stated for inadequate financial support to small and 
medium enterprises include (i) the availability and frequency of budget is arbitrary as opposed to routinely administered, (ii) budget allotted for the program is only sufficient to finance its initial stage, and (iii) budget proposed in programs for micro, small and medium industries have not been included in the "Blue Book of the BAPPEDA and the municipal government", and this has created uncertainty in budget availability.

Incentives and sanctions are key components to induce compliance among target groups. The pricing approach to environmental management has only been introduced recently in Indonesia (e.g. tax reduction for pollution control). Policy makers are still in favor of the command-and-control method through regulations and sanctions. Interagency coordination teams at the sub-national level for monitoring environmental conditions and enforcing regulations have been established. Most of Yogyakarta's small and medium enterprises are not incorporated within the Clean River Program, and respondents noted that weak enforcement dominates those industries not incorporated. Factors contributing to poor monitoring and enforcement include (i) inadequate budget and staffs in the sectoral and non-sectoral agencies, (ii) problems associated with poor socio-economic conditions, low environmental awareness among local communities, and knowledge discrepancy between officials and community members, (iii) enforcement of industrial wastewater discharge regulations through permits, RKL/RPL and standards are conducted by sectoral agencies (e.g. Chamber of Commerce and Industry, Department of Public Health), whereas the semi-autonomous environmental coordinating agency (BAPEDALDA) is not granted enough authority. Officials from the Environmental Impact Mitigation Agency (BAPEDALDA) noted that the commitments of sectoral agencies and the Investment Coordinating Board (BKPMD) are very much influenced by sectoral interests which are in conflict with water conservation and sustainability initiatives. Nonetheless, there has been progress in the institutionalization of the Environmental Impact Assessment (EIA) and the investment screening process for large and medium industries. Table 5 outlines the progress in the institutionalization of the EIA and the LCA. Respondents stated large industries are more likely to have the resources and manpower to incorporate Environmental Management Systems, cleaner production and end of pipe treatments, whereas small and micro industries lack motivation to join programs related to wastewater management due to economic constraints and psychological barriers. They also experience difficulties in utilizing and maintaining installations, and favor immediate income generated from conventional production processes as opposed to sustainable production with cost efficient outcomes in the long run. Moreover, public participation in open discussions were constrained as attendance is prioritized for community leaders. As well, regular public hearing to bridge the gap between enterprises and community members was absent. Scattered locations of small and micro enterprises, lack of space and rolling landscapes create a challenge for installing communal wastewater treatments. Differing perceptions and interests between implementors and target groups often create implementation issues, and key actors are often hard to encounter. All respondents stated the presence of key actors is important to bridge the gap between implementors and target groups. Actors who bridge the gaps are Non-Government Organizations active in environmental protection (WALHI and KEHATI) and informal community leaders. Their roles range from helping local producers to express their needs and motivating community members to bridging the communication gaps between officials and community groups. All respondents noted their contribution in mobilizing communities and the local media to monitor the Clean 
River Program. Some officials perceive the NGOs as having their own private interests and, if not managed carefully, can cause conflicts between community groups and government officials.

Table 5. Progress in the Institutionalization of EIA and LCA (AMDAL)

\begin{tabular}{|c|c|}
\hline No & Progress in the Institutionalization of EIA and LCA (AMDAL) \\
\hline 1 & $\begin{array}{l}\text { The intent of the EIA and LCA has shifted to provide a comprehensive project plan- } \\
\text { ning process. }\end{array}$ \\
\hline 2 & $\begin{array}{l}\text { Central EIA Commissions have been established in } 14 \text { departments (including the } \\
\text { Ministry of Industries) with technical teas and working groups to assist with project } \\
\text { reviews. }\end{array}$ \\
\hline 3 & $\begin{array}{l}\text { A representative from BAPEDALDA or the Environmental Impact Mitigation } \\
\text { Agency chairs the Provincial EIA Commissions established by the governor of each } \\
\text { province. }\end{array}$ \\
\hline 4 & $\begin{array}{l}\text { The formulation of laws and regulations to integrate EIA and LCA into the system of } \\
\text { permits and licenses. }\end{array}$ \\
\hline 5 & $\begin{array}{l}\text { BAPEDALDA or the Environmental Impact Mitigation Agency is responsible for } \\
\text { overall EIA and LCA policies, coordination and quality control in the provincial } \\
\text { level, thus having the authority to formulate budget proposals for EIA and LCA } \\
\text { activities in the province. }\end{array}$ \\
\hline 6 & $\begin{array}{l}\text { Strategies for the Evaluation of Environmental Impacts (SEMDAL) for investment } \\
\text { activities prior to the incorporation of EIA and LCA have been revised and incorpo- } \\
\text { rated to complement the EIA and LCA. }\end{array}$ \\
\hline
\end{tabular}

(Source: Interview Transcript with Respondents, 2018, p. 6)

Officials from the Environmental Impact Management Agency noted the importance of bringing together diverse network of actors. Through joint negotiations legitimized world views are dismantled, routine practices are scrutinized, the adoption and relevance of conventional perceptions are discerned, and existing patterns of governance are altered. Nonetheless, officials also noted that regulations, institutional framework and coordination mechanisms alone do not guarantee the lateral relationship and collaborative mentality envisioned by policy makers. Incorporating a joint innovation strategy requires understanding the interplay of competition and collaboration and how they constrain and enable shared identity while evoking voluntarism for the collective wellbeing. Officials noted that interdependencies between industries, consumer groups and the government can become the core driver of collaborative forms of governance in wastewater management. "...this interdependency is founded in a group's competitive relationship to other external actors. Without the presence of external contestants, the need to collaborate is diminished and so is their willingness to pay the price that it takes to develop and implement new innovative ideas [and good governance]" (Sorensen, 2017, p. 223). 'Contestants' and 'competition' among industries within the Clean River Program foster the enterprises' collaborative mentality to conform with government regulations and compete in achieving the program's targets. Non-government institutions who oversee and monitor the industries' initiatives (e.g. the Provincial Investment Coordinating Board, the media, NGOs and local community groups), when prudently orchestrated 
by a meta-governing institution (the Environmental Impact Management Agency and the Planning Board), can enable industries to achieve intended goals and targets. Hence, competition and collaboration should not be viewed as two contesting entities, but as complementary measures to anchor bottom-up responses into a more synchronized nexus of change and innovations.

\section{Industries' response to 'integrated' wastewater management initiatives}

Tools ranging from end-of-pipe treatment to waste prevention and clean technology have been introduced to industries by the Yogyakarta government. Mentoring and economic instruments have also been adopted to promote compliance. Command and control mechanism is still the main tool used to control wastewater pollution. The Clean River Program was initiated in the mid-1990s to promote voluntary collaboration between large and medium industries and the government for pollution reduction. Micro and small industries have received subsidies for the construction of communal wastewater treatments and were mentored to incorporate low-cost clean(er) production measures. The government and the industries' motives for incorporating environmental management are very different: large and medium industries are interested in environmental care for market expansion, cost-effectiveness and technological advancement, whereas the government's interest is to secure projects and succeed in its policies.

Production increase and market expansion becomes the foremost priority for small and micro enterprises. The following reasons were stated by officials, NGOs and academicians regarding the challenges for internalizing corporate environmental care. First, development is concentrated within the economic and social realms, whereas environmental care involves utilizing environmental potentials to stimulate economic growth. Second, technological development is slow, resources are lacking, and technology transfer proves difficult. Third, the role of industrial innovation as a driving force for environmental improvement has not been widely examined, and prescriptive measures are predominantly used as opposed to communication to induce behavioral change and market instruments to internalize external costs. Lastly, there is a lack of environmental awareness and interests among the general public. Business owners noted that government should reduce the number of permits and taxes and rationalize their functions. Business owners also noted that procedures for tax payment are exceedingly complex and unclear. Moreover, many agencies are perceived unaccountable in enforcing taxes received and spent. Respondents stated the need to simplify procedures for paying taxes, while the number of agencies reduced and synchronized. As well, the same agency should administer the groundwater withdrawal permit and the groundwater withdrawal tax. Respondents from small industries noted the need to differentiate the policies and instruments used. Owners of tofu home industries claimed they cannot be expected to pay effluent discharge fees based on quantity and quality of effluent discharged since they neither have the means nor the equipment to conduct those measurements. They prefer effluent discharge fee be based on the number of kilograms of processed soybean. Some respondents from NGOs noted that compliance from large and medium industries in the Clean River Program becomes questionable since covenants with industries are not enforceable by law, hence police, prosecutors and judges cannot prosecute industries on account of lack of compliance. Industries within the Clean River Program were given up to three warnings for their failure to comply, with the fourth 
lack of compliance being published in local newspapers. Resistance to change, unpreparedness and misconception of product quality in the event of EMS incorporation are also constraints to adopting corporate environmental care. Lack of market for recycled products was also the reason for their reluctance. Large industries within the Clean River Program, such as Sari Husada Ltd which produces milk products, noted that challenges for compliance include constant increase in production, higher level of pollutant generated during the total cleaning period, and the modifications required in the management and technicalities to account for abrupt increase in production.

Officials noted the Clean River Program in particular subscribes to bottom-up forms of self-evaluation as top-down performance indicators tend to block innovative endeavors. Nonetheless, officials also noted that barriers exist, and they are, among others, the fact that entrepreneurs are bad at making compromises. Being visionary and passionate about the business means that entrepreneurs are not keen on adopting the rules and complex government mandates within the program and other intervention mechanisms. As experienced by officials in the Clean River Program, resistance from industries is not uncommon (Sorensen, 2017, p. 222):

The enterprises might end up either being excluded or exclude themselves from the collaboration process. Finally, interactive network arenas that exist outside the ordinary rule and command hierarchy might prove to be innovative, but the consequence of the secluded position of these arenas might be that it is difficult to get the innovation accepted by and disseminated to the larger system. The interactive governance arenas become isolated innovation islands with limited impact.

A handful of the tofu industries outside the formal and intended industrial zones are innovative, aware of the Clean River Program, and have practiced water conservation and communal wastewater treatment initiatives. Nonetheless, their sporadic and isolated nature, as well as their lack of engagement with government officials, deter knowledge sharing, hinder the feedback loop between goal and implementation innovation, and place their innovative processes outside the policy design trajectories. The entrepreneurs within these isolated home industries claim they are aware of the Clean River Program, acquire the required environmental permits and pay their wastewater discharge tax. Nonetheless, they are not incorporated into government programs for sustainable development. Entrepreneurs noted that multilateral knowledge exchange, subsidized clean(er) technology, integration into value chains for fair(er) trade, and incentives for ecofriendly initiatives can motivate small and medium enterprises to incorporate environmental care. These are integrated measures which go beyond prescriptive effluent standards, beyond topdown mandates for end-of-pipe technology, and beyond the use of hard instruments such as taxes, permits and sanctions to account for the costs associated with effluent discharge management. As well, officials noted the need to strike a balance between over-regulation and under-regulation. "Over-regulation of self-governing actors diminishes their motivation for engaging in governance processes because they lose the feeling of ownership that comes with influence. Under-regulation means a lack of pressure on self-governing actors to engage in innovations" (Sorensen, 2017, p. 224). Officials noted the need to appeal to small and medium enterprises for participation in 
the various stages of the Clean River Program and reward them each step of the way through positive reinforcements such as publications in the local media and endowing them with tax cuts and trophies. The willingness of small and micro enterprises to incorporate environmental care is contingent upon the adaptability of policies and programs to bottom-up self-evaluation and initiatives. The meta-governing agencies' role is to foster grassroot experiments and search for locally tailored ways of solving issues and contentions. The role of the meta-governing agency is that of an analyst, consultant and negotiator, facilitating small and medium industries with the much needed 'rowing without steering' mechanism in their corporate affairs.

\section{Theoretical discussion: Direction to control industrial pollution in Yogyakarta}

According to the conventional thinking of the 1970s, the pursuit of environmental policy involved a zero-sum game between protecting the environment and a reduction in the costs of production: more of one necessarily means less of the other. "The sharing of this assumption meant that less attention was necessarily given to creating and nurturing policy institutions whose task it was to find positive-sum solutions to policy and framework issues, by which both environmental protection and economic 'prosperity' could be secured" (Weale, 1992, p. 57). "The task of the public authorities is not so much to secure the right rules of the game, but rather to worry about the attitudes which players bring to the game. In the 1970s policies and frameworks were established by representatives of producers, members of the bureaucracy and a limited range of politicians" (Weale, 1992, p. 57). By the 1980s a much wider range of actors (e.g. consumer goods and community organizations) came to be represented in the process. New groups were incorporated due to their technical competence, their ability to challenge the premises of the policy framework and to exploit the political opportunities that were open to them (Weale, 1992, p. 58). "The positive sum trade gained through the incorporation of varied sets of interests with competing and different interpretations is encompassed through institutional restructuring on the macro and corporate level" (Weale, 1992, p. 58). It is important for environmental policy to note the interrelationships of various subsystems in planning environmental strategies if success is to be achieved. Introducing environmental policy through bureaucratic interventions alone cannot function, but rather through the competitive market economy and the restructuring of the modern state. Through the Clean River Program, interrelationships of wider range of actors are taken into account, and short-term profit takers are made to reflect on their atrocities as consumer groups and the general public are notified of the industries' environmental standing through regular media coverage and public hearings. This has great implications in motivating large and medium industries to incorporate sustainable production measures. Yogyakarta's municipal government is also establishing industrial estates which incorporate the multi-producer system. In multi-producer systems, efforts are being made to optimize material flows and integrate the life cycles of diverse products to limit impact to the environment. Hence, waste from one industry becomes raw materials for another. Small home industries such as tofu and soybean industries are placed adjacent to chicken and pig farms, whereby the soybean residues and wastewater can be fed to the chickens and pigs nearby. There are also catfish farms within the compound which benefit from the soybean residues coming from tofu and soybean industries.

Nonetheless, restructuring the modern state to enable 'voluntary self-regulation' 
in corporate environmental care is difficult due to the following reasons. First, corporate environmental care beyond the adoption of add-on technology for compliance is unattractive due to a perceived lack of increased expenses and low competitiveness. Second, conducive circumstances and market pressure for industries to incorporate waste reduction initiatives are absent. Third, the willingness of businesses to accept state authority, along with its legitimacy in enforcing environmental measure, is weak, whereas participation of pluralistic governance institutions is curtailed due to the perception that waste management is the prerogative of the government, ecologists and few specialists. Lastly, there is no new pattern of interaction among actors within the relevant policy community, as well as no new intellectual thinking to induce institutional restructuring beyond command and control and the narrow development policy orientation.

Devolution in wastewater management takes place through the deliberative participation of cognizant consumers and the general public. Yogyakarta's experience suggests that building sustainable industries is contingent on compensatory investments - namely human knowledge, technology, social capital, and ecologically benign institutions - and how they create alternate discourse and mobilize various sub-groups in challenging the premise of existing policy framework. In Yogyakarta compensatory investments are still in their infancy, hence legal and administrative instruments are still the main driver in conjunction to the government's combining appropriate incentives and disincentives to induce compliance. The case of Yogyakarta suggests the need to internalize externalities within the production process and market price, as well as to institute compensatory investment platforms suited to local complexities. "Ideally, opportunities should arise not between business and the environment, but between progressive environmentally aware businesses on one hand and short-term profit takers on the other" (Weale, 1992, p. 57). Such transformation requires generations to achieve, as well as requiring conducive financial, institutional and political underpinnings capable of addressing macro-economic volatility and trade imbalances.

Creating and devolving autonomy to small and medium enterprises for experimenting feasible options towards environmental care generates environmentally aware businesses in the long run, whereas mandating businesses to undertake complex and energy-consuming government regulations tends to produce short-term profit takers who are both skeptical of government initiatives and resentful of the collaborative process. "To be effective, this bottom-up interaction is in need of skillful top-down meta-governance that frames the interactions in ways that motivate the actors involved to innovate through the strategic institutional design of incentive structure that balance competitive and collaborative patterns of action" (Sorensen, 2017, p. 223). The New Public Management trajectory which encapsulates the Clean River Program provides a clear message to the businesses of the expectations and incentives which arise from the collaborations. As well, businesses are highly aware of the disincentives which arise in the middle term should they decide to exclude or withdraw from the program. This enables businesses to weigh their resources and decisions without overbearing external pressure. The strength of this scheme is that both sides can voluntarily raise their awareness of the degree of their autonomy while adjusting their decisions in response to their heightened learning capacity. This is empowering and can drive the emergence of public-private partnerships and political ethics for the socially and ecologically responsible culture. 


\section{Conclusions and Recommendations}

The case of Yogyakarta suggests numerous constraints for participation in wastewater reduction, including managerial, technical, economic, attitudinal and government constraints. Management constraints include organizational constraints in the form of decision making and inadequate operation and management systems. Technical constraints include impediments to advancements beyond end-of-pipe. Economic constraints include low pricing, low capital availability and difficulties for incorporating productionrelated tax incentives. Attitudinal constraints include lack of sound operational norms, resistance to change and fear of loss. Government constraints include inconsistent environmental and economic growth policies. Pressure from community and NGOs to disclose corporate environmental profiles is very effective to ensure producers take measures for environmental care. Various motives can influence industries to consider adopting corporate environmental care, including social motives, market motives, financial and economic motives and technological advancement motives. Social motives include better corporate image and relations with surrounding communities. Market motives include acquiring new markets, increasing sales, certifying products and anticipating future market requirements. Technological advancement motives include production and waste handling, energy saving methods, adoption of renewable energy sources and improved product quality.

Probable long-term suggestions (15-20 years) include: (i) providing a framework within which industries can pursue their own goals, (ii) examining the role of industries as a driving force for environmental management and emphasizing the use of effective communication and market-oriented strategies, (iii) facilitating database, assistance and mentoring for pollution prevention measures.

Probable mid-term suggestions (10-15 years) include: (i) allowing authorized agencies to enforce clarity and consistency of national and regional policies, (ii) endowing the Environmental Impact Management Agency the autonomy and authority to enforce regulations and control program funding, and endowing the Interagency Coordinating Committee with adequate jurisdiction for coordination, (iii) increasing coordination across agencies to encourage qualified personnel and provide local authorities power to influence allocation of national budgets, and (iv) stipulating minimum condition for communication with business owners, industries and community groups.

Probable short-term measures (5-7 years) include: (i) providing clear legal direction on the function and procedures to acquire RKL, RPL and Nuisance Permit, (ii) reducing number of permits and taxes, rationalizing their functions and synchronizing the agencies involved in granting permits and taxes, (iii) differentiating regulatory and economic instruments to account for the diverging enterprises, (iv) coordinating with law enforcement officials in prosecuting worst offenders, (v) developing industrial estates for micro, small and medium enterprises. In short, there is the need to diversify the policy making community to incorporate groups with different perspectives and interests. 
Probable rapid suggestions (2-5 years) include: (i) incorporate the city's excluded enterprises and reward them with trophies and good publication for their effort, (ii) provide industries with options as to the variations available for collaboration and incentive/reward mechanism, (iii) encourage enterprises to incorporate cleaner production and technology through collective effort and subsidized means, (iv) enable forum group discussions and meet at least once a month to form a tight network of dialogues and foster feedback loops, and (v) assist industries in acquiring permits and provide them with tax cuts for 'compliance'.

\section{Acknowledgments}

I would like to extend my gratitude to Dr. Endro for the assistance and support when writing and revising this article. I would like to thank Prof. Sofia Alisjahbana, the Rector of Universitas Bakrie, Dr. Dudi Rudianto, the Dean of the Faculty of Economics and Social Sciences, and Mr. Aditya Gunawan, MA, the Head of the Political Science Study Program. My best wishes to them all. I would like to extend my utmost gratitude to my mother, daughter, Justin and especially my late father, Kawik Sugiana. I miss you, my father. Rest well in Heaven.

\section{References}

BADAN PENGENDALIAN DAMPAK LINGKUNGAN DAERAH. PROKASIH: Program Kali Bersih Propinsi Daerah Istimewa Yogyakarta. Yogyakarta, Indonesia, 2019.

BADAN PERENCANAAN PEMBANGUNAN NASIONAL. Profil Penduduk Republik Indonesia. Jakarta, Indonesia, 2019.

DEPARTEMEN PERINDUSTRIAN DAN PERDAGANGAN. Data Sentra Industri Kecil di Yogyakarta Tahun 2018/2019. Yogyakarta, Indonesia, 2018.

FISHER, K. Environmental strategies for industries. Washington: Island Press, 1993.

HUBER, J. Ecological modernization. Away from scarcity, soberness and bureaucracy. Den Haag: SDU, 1991.

MOL, APJ. The refinement of production: ecological modernization theory and the chemical industry. Amsterdam: University of Amsterdam Press, 1995.

SMALLWOOD, F. The politics of implementation. New York: St Martin's Press, 1979.

SORENSEN, E. Governance and innovation in the public sector. In: . The Oxford Handbook of Governance. Oxford University Press, Oxford, UK: David Levi-Faur, 2017. P. 215-227. 
STERLING, G. Managing the public sector. Homewood, Illinois: The Dorsey Press, 1982.

WEALE. The new politics of pollution. London, Great Britain: Bell and Bain Ltd, 1992. 


\section{Astrid Meilasari-Sugiana}

$\square$ astrid.sugiana@bakrie.ac.id

ORCiD: https://orcid.org/ 0000-0002-9671-4280
Submitted on: 26/03/2019

Accepted on: 04/07/2021

$2021 ; 24 \mathrm{e}: 02601$

How to cite: MEILASARI-SUGIANA, A. Industrial Wastewater Management in Yogyakarta, Indonesia: Direction to Control Industrial Pollution. Ambiente \& Sociedade. São Paulo, v. 24, p. 1-21, 2021. 


\title{
A Política da Gestão de Águas Residuais Industriais em Yogyakarta, Indonésia: Possibilidades para Controlar a Poluição Industrial
}

\author{
Astrid Meilasari-Sugiana
}

São Paulo. Vol. 24, 2021

Artigo Original
Resumo: Crescendo a concorrência através da diminuição do consumo de água e o rápido crescimento de pequenas empresas sem medidas de controle de poluição sugerem a necessidade de uma estrutura institucional aprimorada para gerenciar a descarga de águas residuais. A pesquisa analisa a adequação de regras institucionais e a eficácia de ferramentas e instrumentos no gerenciamento de descargas de efluentes industriais em Yogyakarta, na Indonésia, por meio de estudo de caso, pesquisa qualitativa com amostragem proposta e de pesquisas "snowball sampling". Os resultados da pesquisa sugerem ênfase excessiva em medidas prescritivas, falta de mecanismos adequados de coordenação e falta de instrumentos políticos eficazes para o controle da poluição entre pequenas e médias empresas. É necessário estabelecer uma agência fiscalizadora com autonomia para obter consistência, diferenciar instrumentos regulatórios e econômicos, reduzir o número de licenças ambientais e introduzir incentivos para o desenvolvimento de propriedades industriais.

Palavras-chave: Gerenciamento de efluentes industriais, programas de ações institucionais, medidas regulatórias, instrumentos econômicos, participação deliberativa.

Como citar: MEILASARI-SUGIANA, A. A Política da Gestão de Águas Residuais Industriais em Yogyakarta, Indonésia: Possibilidades para Controlar a Poluição Industrial. Ambiente $\mathbb{\&}$ Sociedade. São Paulo, v. 24, p. 1-21, 2021. 


\title{
La política de gestión de aguas residuales industriales en Yogyakarta, Indonesia: posibilidades para Controlar la contaminación industrial
}

\author{
Astrid Meilasari-Sugiana
}

São Paulo. Vol. 24, 2021

Artículo original
Resumen: El desarollo industrial es importante para la economia. Demasiada competicion sobre menguante agua fresca y el crecimiento de las industrias pequenas sin control de la polucion demonstra que es necesario para mejorar la institucion que manejar aguas residuales. Este investigacion investiga la aceptabilidad de la institucion y la efectividad de la instrumenta para manejar aguas residuales con estudio de caso. Esta investigacion utilisa el muestreo deliberado (purposive sampling). El resultado demonstra que ahi esta demasiada enfasis en medidas prescriptivas y pequena cooperacion y coordinacion. Es muy importante para diferenciar la regulacion y instrumentos economicos adoptados, para reducir los permisos y para introducir incentivos en la formacion de estados industriales. A traves de la programa que se llama rio limpio (Clean River Program), el gobierno puede supervisar y publicar la polucion en los periodicos.

Palabras-clave: Gestion de aguas residualis industrial, arreglos institucionales, medidas regulatorias, instrumentos economicos, participacion deliberada.

Como citar: MEILASARI-SUGIANA, A. La política de gestión de aguas residuales industriales en Yogyakarta, Indonesia: posibilidades para Controlar la contaminación industrial. Ambiente $\mathbb{\&}$ Sociedade. São Paulo, v. 24, p. 1-21, 2021.

DOI: http://dx.doi.org/10.1590/1809-4422asoc20190260r1vu2021L4AO 